\title{
Isolation and Characterization of Potential Probiotic Strains Isolated from Traditional Indian Fermented Foods
}

\author{
Neha Khagwal ${ }^{1}$, D.C. Sharma ${ }^{2}$ and P.K. Sharma ${ }^{3} *$ \\ ${ }^{1}$ Department of Microbiology, Ch. Charan Singh University, Meerut-250004 (India) \\ ${ }^{2}$ Department of Microbiology, Dr. Shakuntala Mishra National Rehabilitation University, \\ Lucknow-226017 (India) \\ ${ }^{3}$ Department of Genetics and Plant Breeding, Ch. Charan Singh University, Meerut-250004 \\ (India)
}

*Corresponding author

\begin{abstract}
A B S T R A C T
Keywords

Lactobacillus,

Probiotics,

Fermented foods,

Lactic acid bacteria,

Acid tolerance

Article Info

Accepted:

07 February 2019

Available Online:

10 March 2019

The present study explored the traditional Indian fermented food samples for potential probiotic strains with superior probiotic properties to that of commercially available strain. A total of 102 food samples were collected aseptically and 200 isolates were purified using MRS media. 132 were identified as Gram-positive bacteria and 43 were identified as yeast cultures. On the basis of morphological and biochemical properties, 120 isolates were provisionally identified as Lactobacillus spp. These isolates were evaluated for desired probiotic properties such as acid, bile and pancreatin tolerance, and only seven isolates were found to pass these tests. These seven isolates were further evaluated for other properties, including carbohydrate fermentation, autoaggregation, haemolysis and antibiotic resistance profile, on the basis of which, the strains $4 A$ and $21 C$ were found to have excellent probiotic potential and were also found superior when compared with the commercially available probiotic strain (control) Lactobacillus casei Shirota (LcS).
\end{abstract}

\section{Introduction}

The word probiotic comes from the Greek "pro bios", meaning 'for life' and was first used by Lilly and Stillwell (1965) to describe "substances secreted by one microorganism that stimulate the growth of another (Sayes et al., 2018). Probiotics are defined by WHO/FAO (2006) as "live microorganisms, which when consumed in adequate amounts confer health benefit to the host". The most commonly used probiotic strains belongs to heterogeneous group of lactic acid bacteria (LAB); Lactobacillus, Enterococcus, Streptococcus, Leuconostoc, Lactococcus, Pediococcus, Bifidobacterium and yeast Saccharomyces boulardii. LAB, especially Lactobacillus, have received much attention due to their "generally recognized as safe" (GRAS) status and because of their health 
promoting benefits as probiotics (Zielinska $e t$ al., 2015).

Nutritional benefits exerted by probiotics include their role in enhancing the bioavailability of various minerals, digestibility of protein and synthesis of vitamins in yogurt (Radulovic et al., 2010). The reported therapeutic benefits of probiotic consumption include lipid and serum cholesterol reduction, enhancement of immune function, anticancer, anti-allergic, antioxidative and antimicrobial properties (Lee et al., 2014).

The selection criteria of probiotics for human consumption suggest that they should be gastric juice and bile tolerant, safe, and viable; must be able to survive through the gastrointestinal tract in order to adhere and colonize epithelial cells (Yadav et al., 2015). Moreover, probiotic strain must possess the ability to be manufactured under industrial conditions, survival and retention of their functionality during storage, heat tolerance, phage resistance and sensory properties (Nahaisi et al., 2014).

Fermentation is one of the oldest food technology used worldwide for development of a diversity of aroma, flavor, texture, preservation and biological enrichment of food products by different microbial population using traditional methods. Fermented vegetable foods like 'gundruk', 'sinki'; cereal/pulse based fermented foods like 'kinema', 'tungrymbai', 'dosa'; fermented milk beverages like 'dahi', 'churpa' and alcohol like 'ghanti' are indigenous to people of India (Rawat et al., 2018). Some internationally well-known fermented foods include 'kimchi', 'sauerkraut', 'kombucha', 'yogurt', 'tempeh', 'kefir', etc.

Increasing levels of multidrug resistance pathogens along with increasing demands for natural substitutes for drugs and the emergence of scientific and clinical evidence showing the efficacy of probiotic strains has led to examine probiotics and other alternatives to pharmaceutical remedies. Due to growing consciousness about potential health benefits of LAB, there is an abundant opportunity available to explore a variety of Indian fermented foods for the isolation of new LAB strains for their potential role in probiotic research. Therefore, the present investigation was designed to isolate the best suited bacterial strain(s) from the fermented foods that can be used as a potential probiotic.

\section{Materials and Methods}

\section{Sample collection and isolation of cultures}

A total no. of 102 fermented food samples like homemade curd, butter milk, dosa batter, idli batter, jalebi batter and bhatura dough were collected aseptically and stored at $4{ }^{\circ} \mathrm{C}$ till further processing. One gram or $1 \mathrm{ml}$ of sample was suitably diluted and was spread on Man Rogosa Sharpe (MRS) agar and incubated at $37^{\circ} \mathrm{C}$ for $24-48 \mathrm{~h}$. Isolated colonies of distinct morphology were sub cultured on MRS plates. All the isolates were preserved in $50 \%$ glycerol stocks at $-20^{\circ} \mathrm{C}$ for further use (Khagwal et al., 2014). Pure culture of Lactobacillus casei Shirota (LcS) was isolated from probiotic drink 'Yakult' and was used as control for catalase, oxidase, acid, bile, pancreatin, carbohydrate fermentation and autoaggregation tests.

\section{Phenotypic characterization}

The isolated colonies were studied for their colony morphology; provisional identification of the isolates was based on Gram's staining, endospore staining, catalase and oxidase tests. Only those isolates that were Gram-positive, endospore, catalase and oxidase negative were selected and subjected to following tests to 
qualify for probiotics parameters. E. coli and Pseudomonas aeruginosa were used as positive control for catalase and oxidase test respectively whereas $\mathrm{LcS}$ served as negative control for both the tests. All the tests were performed in duplicate (Li et al., 2014).

\section{Acid tolerance}

$1 \%$ mother culture of selected isolate was transferred to MRS broth with $\mathrm{pH} 3$ [adjusted using $1 \mathrm{~N}$ hydrochloric acid (HCL)] which was then serially diluted and $100 \mu \mathrm{l}$ was plated on MRS plates at 0,3 and $6 \mathrm{~h}$ and incubated at $37^{\circ} \mathrm{C}$ for $48 \mathrm{~h}$. The cultures which passed $\mathrm{pH} 3$ test were tested for their ability to survive at $\mathrm{pH} \quad 2.5$ following the same procedure. Viability of the isolates was assessed by plate count method and expressed in terms of colony forming units (cfu) as $\log \mathrm{cfu} / \mathrm{ml}$. Survival rate was given by following formula (Gonzalez-Vazquez et al., 2015).

$\%$ survival rate $=\left(\log \mathrm{cfu} 3^{\text {rd }}, 6^{\text {th }} \mathrm{h} / \log \mathrm{cfu} 0^{\text {th }}\right.$ h) x 100

\section{Bile tolerance}

The bile tolerance of the isolates was determined by transferring $1 \%$ of seed culture to MRS broth supplemented with $0.3 \%$ bile which was then serially diluted and spread on MRS agar plates at 0,3 and $6 \mathrm{~h}$ and incubated at $37^{\circ} \mathrm{C}$ for $48 \mathrm{~h}$ (Shehata et al., 2016). Viability of the isolates was assessed by plate count method and expressed as $\log \mathrm{cfu} / \mathrm{ml}$. Survival rate was given by following formula.

$\%$ survival rate $=\left(\log \mathrm{cfu} 3^{\text {rd }}, 6^{\text {th }} \mathrm{h} / \log \mathrm{cfu} 0^{\text {th }}\right.$ h) $x 100$

\section{Pancreatin tolerance}

$1 \%$ of mother culture was inoculated in MRS broth containing $0.5 \%$ pancreatin which was then serially diluted and from this last dilution
$100 \mu \mathrm{l}$ was spreaded on MRS plates at 0,3 and $6 \mathrm{~h}$ and incubated at $37^{\circ} \mathrm{C}$ for $48 \mathrm{~h}$ (Rubio et al., 2014). Viability of the isolates was assessed by plate count method and expressed as $\log \mathrm{cfu} / \mathrm{ml}$. Survival rate was given by following formula.

$\%$ survival rate $=\left(\log\right.$ cfu $3^{\text {rd }}, 6^{\text {th }}$ h/ $\log$ cfu $0^{\text {th }}$ h) $\mathrm{x} 100$

\section{Auto aggregation test}

The auto aggregation capability of bacteria helps in maintaining the bacterial population in the gastrointestinal tract. Bacterial cultures were grown for $18 \mathrm{~h}$ at $37^{\circ} \mathrm{C}$ in MRS broth. The cells were harvested by centrifugation at $5000 \mathrm{~g}$ for $15 \mathrm{~min}$, washed twice and resuspended in phosphate buffer saline (PBS).

Cell suspensions (4ml) were mixed by vortexing for $10 \mathrm{~s}$ and autoaggregation was determined during $5 \mathrm{~h}$ of incubation at room temperature. $0.1 \mathrm{ml}$ of the upper suspension was transferred to another tube with $3.9 \mathrm{ml}$ of PBS every hour and the absorbance (A) was measured at $600 \mathrm{~nm}$. The autoaggregation percentage was expressed as: $1-\left(\mathrm{A}_{t} / \mathrm{A}_{0}\right) \times 100$, where $A_{t}$ represents the absorbance at time $t=$ $1,2,3,4$ or $5 \mathrm{~h}$ and $\mathrm{A}_{0}$ is the absorbance at $\mathrm{t}=$ 0 . The final autoaggregation value was indicative of the isolates' ability to aggregate among themselves (Kos et al., 2003; Botta et al., 2014).

\section{Acid production from carbohydrate}

The production of acid and gas from glucose was determined in phenol red broth base supplemented with $1 \%$ glucose and gas produced was trapped in durham tubes at temperatures $15^{\circ} \mathrm{C}$ and $37^{\circ} \mathrm{C}$. The isolates were categorized on the basis of fermentation group. The fermentation of glucose without gas, growth at $37^{\circ} \mathrm{C}$ and no growth at $15^{\circ} \mathrm{C}$ identifies obligately homofermentative 
lactobacilli (OHOL); growth both at $15^{\circ} \mathrm{C}$ and $37^{\circ} \mathrm{C}$ without gas production is characteristic of facultatively heterofermentative lactobacilli (FHEL), whereas gas production at $37^{\circ} \mathrm{C}$ and variable growth at $15^{\circ} \mathrm{C}$ were characteristic of obligately heterofermentative lactobacilli (OHEL) (Koll et al., 2010).

\section{Haemolysis assay}

For evaluating haemolytic ability of the isolates test culture was streaked onto blood agar plates containing 5\% (v/v) of sheep blood and incubated at $37^{\circ} \mathrm{C}$ for $48 \mathrm{~h}$.

Haemolysis was evaluated by examining plates for the signs of $\alpha$-haemolysis (greenhued zones around colonies), $\beta$-haemolysis (clear zones around colonies) or $\gamma$-haemolysis (no zones around colonies (Borah et al., 2016).

\section{Antibiotic susceptibility}

The selected strains were tested for their antibiotic susceptibility by using antibiotic disc diffusion method. $100 \mu 1$ freshly prepared broth culture was then spreaded on to MullerHinton agar plates and allowed to dry. Antibiotic discs were placed on the inoculated plates and were incubated for $48 \mathrm{~h}$ at $37^{\circ} \mathrm{C}$. The zone of inhibition diameter around each disc was measured. The results were expressed as susceptible (S), intermediate (I) and resistant (R). The test was performed according to Clinical and Laboratory Standards Institute (CLSI) standard procedure (Li et al., 2014).

\section{Molecular identification}

The best isolates selected based on their probiotic properties were, identified using $16 \mathrm{~S}$ rRNA sequencing. The purified cultures were sent for commercial sequencing and the sequence data obtained was compared using basic alignment search tool (BLAST).

\section{Results and Discussion}

\section{Sample collection and isolation of cultures}

A total of 200 microbial cultures were isolated from 102 food samples based on their colony morphology. The samples that were used for the isolation of probiotic bacteria are an indigenous part of Indian diet. Some of these fermented foods are reported to have significant medicinal properties and are consumed unknowingly as, probiotic food/drinks by local people. Zeilinska et al., (2015) isolated 38 strains from six samples of cucumber pickles and cabbage pickles.

\section{Phenotypic characterization}

The isolates were provisionally identified based on the results of Gram's staining, endospore staining, catalase and oxidase test (Hammes et al., 2009). Out of 200 isolates, 132 were identified as Gram-positive bacterial rods and coccobacilli and 43 were identified as yeasts. From 132 bacterial isolates, 12 were identified as endospore formers. Remaining 120 bacterial isolates gave negative results for both catalase and oxidase tests. The results of above tests suggested that these isolates belonged to the Lactobacillus genus according to Bergey's Manual of Bacteriology. Similar findings were also reported by Yadav et al., (2016).

\section{Acid tolerance}

In order to exert beneficial effects, the probiotic bacteria must be able to survive harsh conditions of gastrointestinal tract. These bacteria must be able to withstand low $\mathrm{pH}$ conditions of stomach for a minimum of 90 min before being able to colonize the gut and show their health promoting benefits (Haghshenas et al., 2015). pH of stomach can be as low as 1.0. Usually, in most in-vitro assays $\mathrm{pH}-3$ is preferred because of the 
buffering action of food matrix which has shielding effect on the ingested bacteria (Zielinska et al., 2015). For this reason, the assessment of acid tolerance was performed at $\mathrm{pH}-3$ and $\mathrm{pH}-2.5$. Out of 120 isolates, 81 stains were able to survive $\mathrm{pH}-3$ for $3 \mathrm{~h}$ and 57 strains survived the same $\mathrm{pH}$ for $6 \mathrm{~h}$. The above 81 tolerant isolates were then tested for their ability to survive $\mathrm{pH}-2.5$, and it was found that only 34 strains were able to survive at this $\mathrm{pH}$ for $3 \mathrm{~h}$ and none survived for $6 \mathrm{~h}$. Owusu-Kwarteng et al., (2015) stated that a probiotic culture with survival rate of more than $80 \%$ at $\mathrm{pH}-2.5$ after $4 \mathrm{~h}$ incubation can be considered resistant to low $\mathrm{pH}$. Similar findings were reported from previous studies, where different Lactobacillus species of various origins were able to retain their viability at $\mathrm{pH}$ values ranging from 3-7 for $3 \mathrm{~h}$ (Adetoye et al., 2018). Comparison of percent survival rate of overall best 7 isolates and control (LcS) in $\mathrm{pH} 3$ and $\mathrm{pH} 2.5$ are shown in Figure 1 and 2.

\section{Bile tolerance}

Ability to tolerate bile salt is required for colonization and metabolic activity of bacteria in the small intestine and is thus considered an important parameter for evaluating the probiotic potential of the isolates. Bile salt concentration in small intestine is approximately $0.3 \%$, therefore survival percentage of the isolates were determined after exposure to $0.3 \%$ bile salt for $3 \mathrm{~h}$ and $6 \mathrm{~h}$ (Park et al., 2015). Out of 81 isolates that qualified the acid tolerance test, 29 strains were able to withstand $0.3 \%$ bile for $3 \mathrm{~h}$ and 19 strains survived the same bile concentration for $6 \mathrm{~h}$. Bile salt resistance could possibly be due to the ability of bacteria to deconjugate bile salts, which is associated to the capability to eliminate cholesterol from the intestinal environment (Baick et al., 2015). Shehata et al., (2016) reported survival percentage of various Lactobacillus species in $0.3 \%$ bile after $3 \mathrm{~h}$ incubation with $85 \%$ being the highest surviving percentage for one of their isolates. Figure 3 shows comparative \% survival rate of the overall 7 best isolates and the control in $0.3 \%$ bile.

\section{Pancreatin tolerance}

Pancreatic enzymes aid in digestion of carbohydrates, proteins and fats of our food and are released through the pancreatic duct into the small intestine. Tolerance to pancreatin is considered as another important criterion for predicting the survival of a strain in the gastrointestinal environment (FAO/WHO, 2006). Out of 19 isolates that qualified bile test only 5 strains survived $0.5 \%$ pancreatin at $3 \mathrm{~h}$ incubation and 7 strains survived $6 \mathrm{~h}$ incubation. The results were supported by various studies where isolates were able to tolerate $0.5 \%$ pancreatin (Rubio et al., 2014; Tallapragada et al., 2018). Figure 4 shows \% survival rate of the overall 7 best isolates and the control in $0.5 \%$ pancreatin.

\section{Auto aggregation test}

Auto aggregation ability indicates the adhesion ability of strains to human intestinal cells which is regarded as a beneficial characteristic for probiotics and helps providing a competitive advantage by preventing immediate elimination of the strains by peristalsis (Kos et al., 2003). 21C showed the highest auto-aggregation ability of 93\% followed by $4 A$ which possessed autoaggregation ability of $79 \%$ whereas $\mathrm{LcS}$ showed 59\% auto-aggregation ability. The autoaggregation percentage increased with incubation time and results were consistent with previous studies (Borah et al., 2016). Andrabi et al., (2016) documented 80.33\% auto-aggregation percentage as the highest in their study involving various LAB isolates. Figure 5 represents the autoaggregation percentage of overall 7 best isolates and control. 
Table.1 Acid and gas production from phenol red glucose broth at $15^{\circ} \mathrm{C}$ and $37^{\circ} \mathrm{C}$

\begin{tabular}{|c|c|c|c|c|c|}
\hline S. NO. & STRAIN ID & \multicolumn{2}{|c|}{$\operatorname{AT} 15^{\circ} \mathrm{C}$} & \multicolumn{2}{|c|}{ AT $37^{\circ} \mathrm{C}$} \\
\hline & & \multicolumn{2}{|c|}{ ACID GAS } & \multicolumn{2}{|c|}{ ACID GAS } \\
\hline 1. & $4 \mathrm{~A}$ & $\rightarrow$ & $\rightarrow$ &,++ & $\rightarrow$ \\
\hline 2. & $20 \mathrm{~A}$ & , & $\rightarrow$ &,++ & -, \\
\hline 3. & $21 \mathrm{C}$ &,++ & $\rightarrow$ &,++ & -, \\
\hline 4. & $47 \mathrm{~A}$ &,++ &,++ &,++ &,++ \\
\hline 5. & $100 \mathrm{~A}$ & _, & _, &,++ & _, \\
\hline 6. & $101 \mathrm{~A}$ & $\rightarrow$ & $\rightarrow$ &,++ & -, \\
\hline 7. & $102 \mathrm{~A}$ & - & - &,++ & - \\
\hline 8. & $\mathrm{LcS}$ & $\rightarrow$ & , &,++ & $\rightarrow$ \\
\hline & $\begin{array}{l}\text { OHOL oblig } \\
\text { FHEL facult } \\
\text { OHEL oblig }\end{array}$ & $\begin{array}{l}\text { ioferm } \\
\text { terofe } \\
\text { rofern }\end{array}$ & $\begin{array}{l}\text { lact } \\
\text { ive la } \\
\text { e lact }\end{array}$ & $\begin{array}{l}+-) \\
+-+ \\
+++\end{array}$ & \\
\hline
\end{tabular}

Table.2 Antibiotic susceptibility of isolates

\begin{tabular}{|c|c|c|c|}
\hline Antibiotics & Dose $(\boldsymbol{\mu g} /$ disc $)$ & $\mathbf{4 A}$ & 21C \\
\hline Chloramphenicol & $30 \mu \mathrm{g}$ & $35 \mathrm{~mm}(\mathrm{~S})$ & $42 \mathrm{~mm}(\mathbf{S})$ \\
\hline Erythomycin & $15 \mu \mathrm{g}$ & $30 \mathrm{~mm}(\mathrm{~S})$ & $38 \mathrm{~mm}(\mathrm{~S})$ \\
\hline Gentamycin & $10 \mu \mathrm{g}$ & $18 \mathrm{~mm}(\mathrm{~S})$ & $29 \mathrm{~mm}(\mathrm{~S})$ \\
\hline Nalidixic acid & $30 \mu \mathrm{g}$ & $12 \mathrm{~mm}(\mathrm{I})$ & $17 \mathrm{~mm}(\mathrm{I})$ \\
\hline Penicillin G & $10 \mu \mathrm{g}$ & $35 \mathrm{~mm}(\mathrm{~S})$ & $38 \mathrm{~mm}(\mathrm{~S})$ \\
\hline Streptomycin & $10 \mu \mathrm{g}$ & $15 \mathrm{~mm}(\mathrm{I})$ & $12 \mathrm{~mm}(\mathrm{I})$ \\
\hline
\end{tabular}

$\mathrm{R}$, resistant (inhibition zone diameter $<\_12 \mathrm{~mm}$ ); $\mathrm{S}$, susceptible (inhibition zone diameter >_ $17 \mathrm{~mm}$; I, intermediate (inhibition zone diameter between $12-1 \overline{7} \mathrm{~mm}$ )

Fig.1 Percent survival rate of 7 isolates and control at $\mathrm{pH} 3$

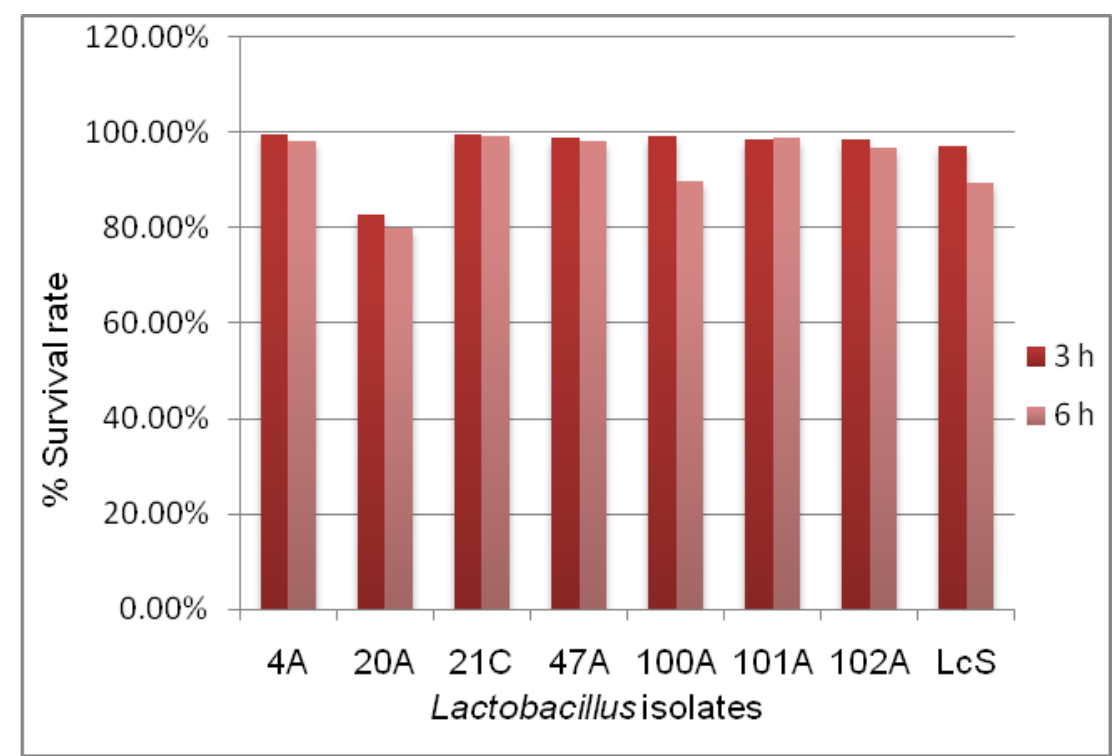


Fig.2 Percent survival rate of 7 isolates and control at $\mathrm{pH} 2.5$

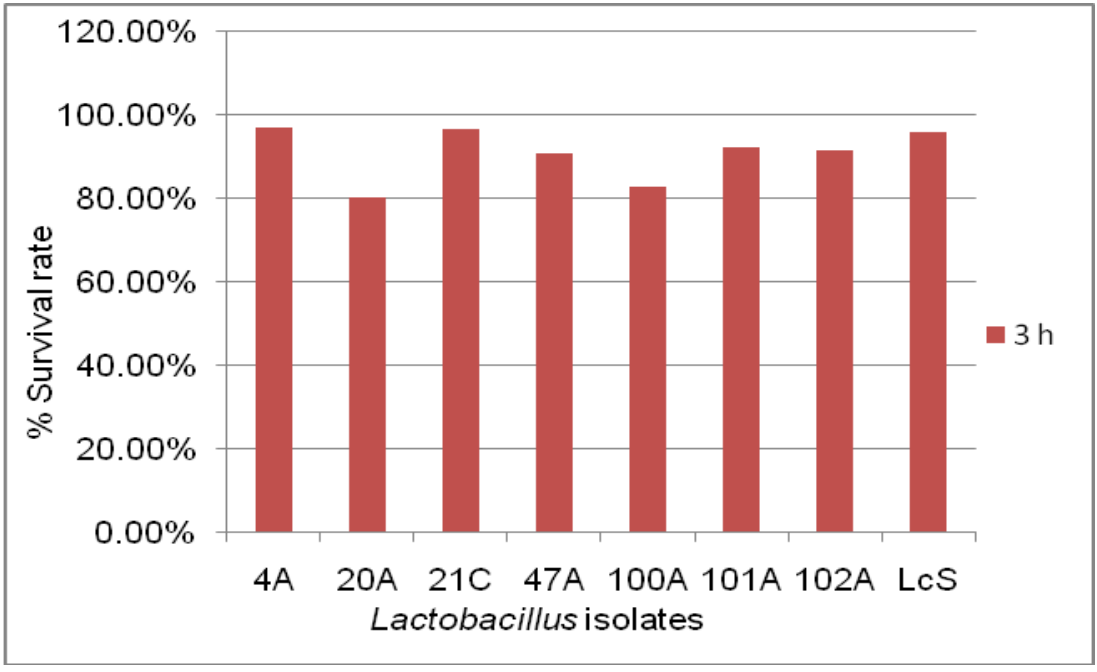

Fig.3 Percent survival rate of 7 isolates and control at $0.3 \%$ bile

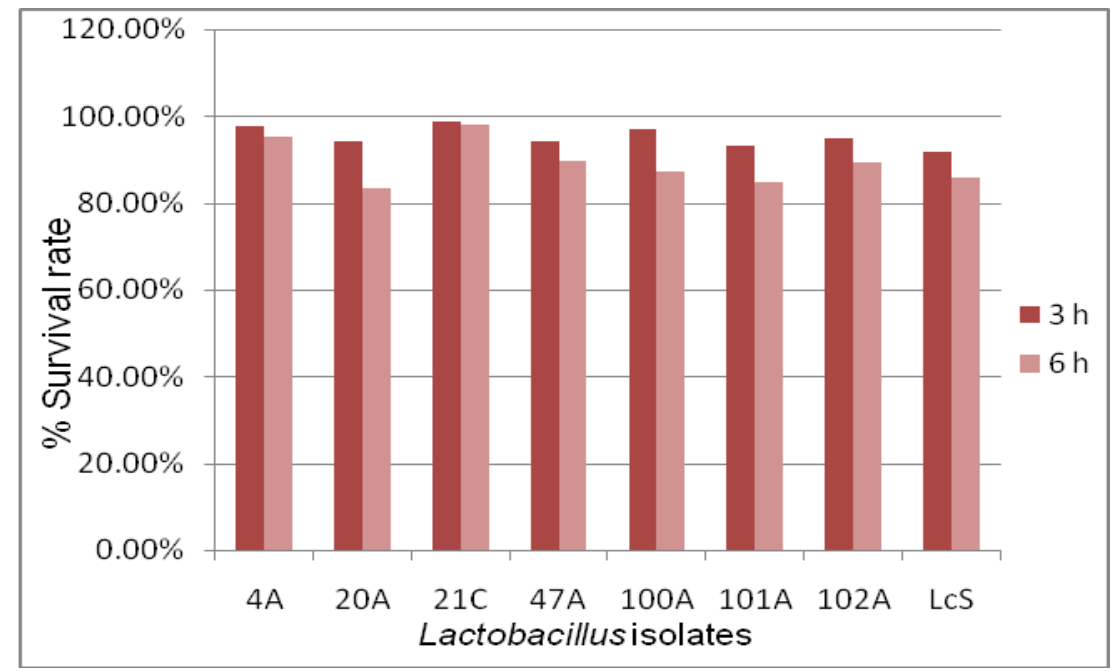

Fig.4 Percent survival rate of 7 isolates and control at $0.5 \%$ pancreatin

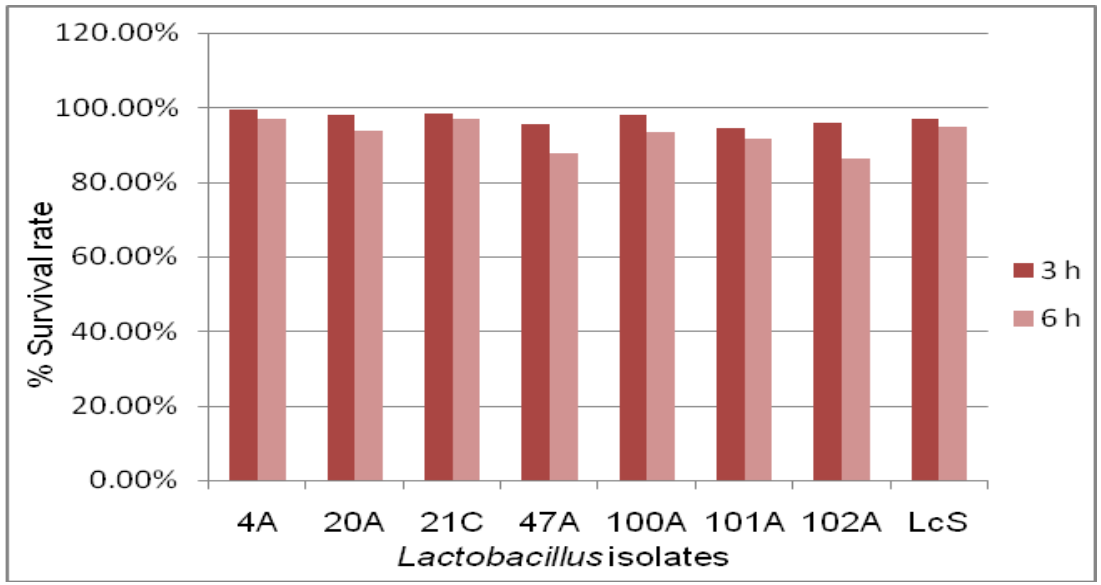


Fig.5 Autoaggregation percentage of 7 isolates and control

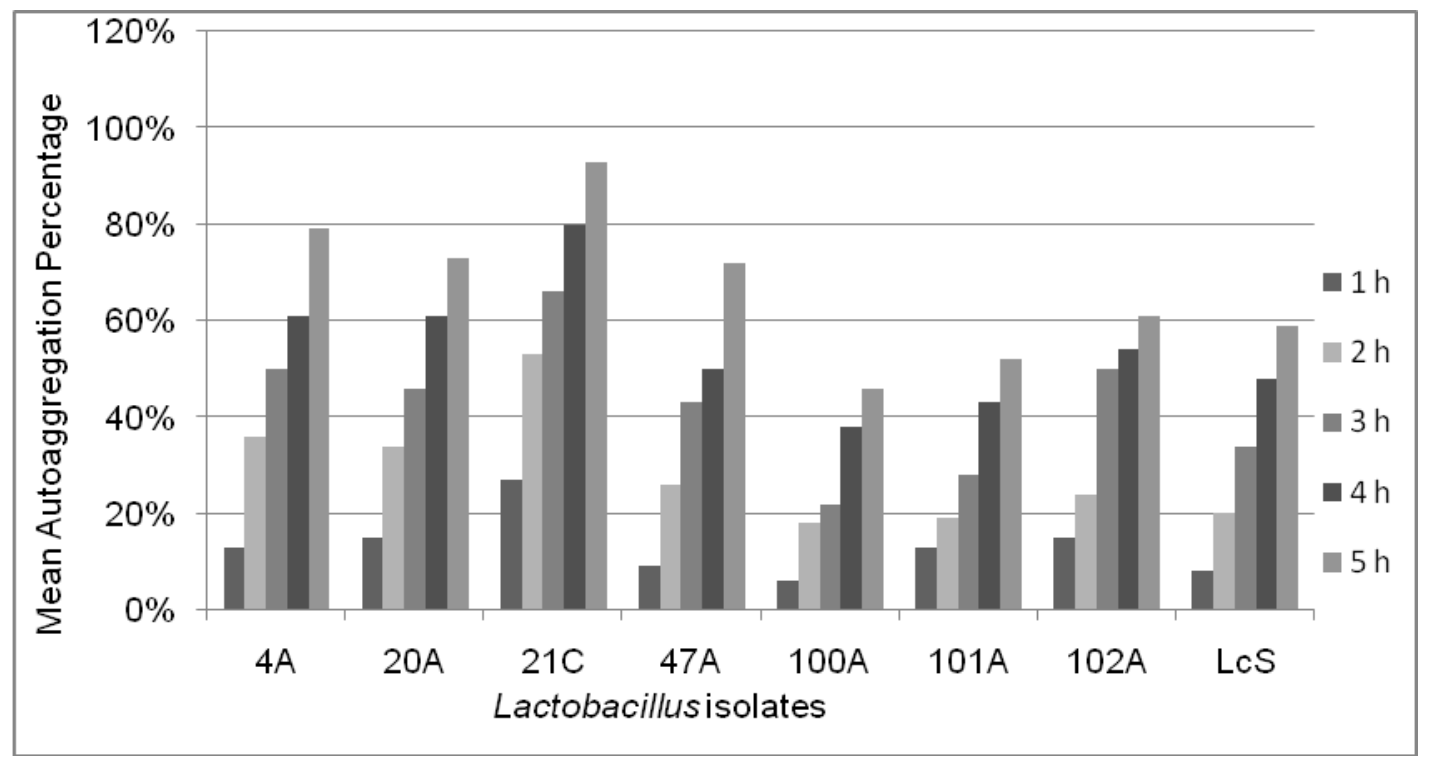

\section{Acid production from carbohydrate}

To determine fermentation group, some physiological properties were assessed using glucose as the test sugar. From final selected 7 isolates, 5 were identified to be OHOL, 1 was identified to be FHEL and 1 was OHEL (Table 1). LcS was identified as OHOL. Koll et al., (2010) also categorized their isolates into different fermentation groups.

\section{Haemolysis assay}

The two isolates $4 A$ and $21 C$ with best results were tested for their non-pathogenic character by streaking them on blood agar plates. Tested strains showed no haemolysis $(\gamma$ haemolysis). Evaluation of haemolytic activity is an important safety requirement frequently used to assess potential probiotic strains. Usually no haemolysis by the test strain is the indicative of its safety for human use (Owusu-Kwarteng et al., 2015).

\section{Antibiotic susceptibility}

The results of susceptibility test (Table 2) of isolates $4 A$ and $2 l C$ against six antibiotics demonstrated that the strains were susceptible to chloramphemicol, erythomycin, gentamycin and penicillin. These isolates showed intermediate sensitivity to nalidixic acid and streptomycin only. None of the isolates showed resistance to any antibiotic drug (inhibition zone diameter <_ $12 \mathrm{~mm}$ ).

\section{Molecular identification of strains}

Finally selected isolates $4 A$ and $21 C$ were subjected to BLAST analysis based on their $16 \mathrm{~S}$ rRNA sequences. The results showed that strain $4 A$ shared $99 \%$ identity with Lactobacillus fermentum and the strain $21 C$ shared 99\% identity with Lactobacillus plantarum. Sequences of both the strains have been submitted to GenBank database of NCBI with accession no. MK367582 for $4 A$ and MK360767 for 21C.

\section{Acknowledgments}

This research was supported by the Department of Microbiology, Chaudhary Charan Singh University, Meerut, India. All the authors of the research paper and books cited are highly acknowledged. 


\section{References}

Adetoye, A., Pinloche, E., Adeniyi, and B. A., Ayeni, F. A. 2018. Characterization and anti-salmonella activities of lactic acid bacteria isolated from cattle faeces. BMC Microbiology. 18(96): 1-11.

Andrabi, S. T., Bhat, B., Gupta, M., and Bajaj, B. K. 2016. Phytase-producing potential and other functional attributes of lactic acid bacteria isolates for prospective probiotic applications. Probiotics \& Antimicro. Prot. 8: 121-129.

Baick, S. C., and Kim, C. H. 2015. Assessment of characteristics and functional properties of Lactobacillus species isolated from kimchi for dairy use. Korean J. Food Sci. An. 35(3): 339-349.

Borah, D., Gogoi, O., Adhikari, C., and Kakoti, B. B. 2016. isolation and characterization of the new indigenous Staphylococcus sp. DBOCP06 as a probiotic bacterium from traditionally fermented fish and meat products from Assam state. Egyptian Journal of Basic and Applied Sciences. 3: 232-240.

Botta, C., Langerholc, T., Cencic, A., and Cocolin, L. 2014. In vitro selection and characterization of new probiotic candidates from table olive microbiota. Plos One. 9: 1-15.

FAO/WHO. 2006. Probiotics in food. Health and nutritional properties and guidelines for evaluation. FAO Food and Nutrition Paper 85. FAO, Rome, Italy

Gonzalez-Vazquez, R., Azaola-Espinosa, A., Mayorga-Reyes, L., Reyes-Nava, L. A., Shah, N. P., and Rivera-Espinoza, Y. 2015. Isolation, identification and partial characterization of a Lactobacillus casei strain with bile salt hydrolase activity from pulque. Probiotics and Antimicro. Prot. 7: 242248.

Haghshenas, B., Nami, Y., Haghshenas, M., Abdullah, N., Rosli, R., Radiah, D., and Khosroushahi, A. Y. 2015. Bioactivity characterization of Lactobacillus strains isolated from dairy products. Microbiology Open. 4(5): 803-813.

Hammes, P. H., and Hertel, C. 2009. Lactobacillaceae. In: Bergey's Manual of Systematic Bacteriology (Eds.) P. D. Vos, G. M. Garrity, D. Jones, N. R. Krieg, W. Ludwig, F. A. Rainey, K. H. Schieifer, and W. B. Whitman. $3^{\text {rd }}$ edn. Springer, New York, Pp. 456-479.

Khagwal, N., Sharma, P. K., and Sharma, D. C. 2014. Isolation and screening of Lactobacillus spp. for the development of potential probiotics. Afr. J. Microbiol. Res. 8(15): 1573-1579.

Koll, P., Mandar, R., Smidt, I., Hutt, P., Truusalu, K., Mikelsaar, R. H., Shchepetova, J., Krogh-Andersen, K., Marcotte, H., Hammarstrom, L., and Mikelsaar, M. 2010. Screening and evaluation of human intestinal lactobacilli for the development of novel gastrointestinal probiotics. Current Microbiol. 61: 560-565.

Kos, B., Suskovic, J., Vukovic, S., Simpraga, M., Frece, and J., Matosic, S. 2003. Adhesion and aggregation ability of probiotic strain Lactobacillus acidophilus M92. Journal of Applied Microbiology. 94: 981-987.

Lee, N. K., Kim, S. Y., Han, K. J., Eom, S. J., and Paik, H. D. 2014. Probiotic potential of Lactobacillus strains with anti-allergic effects from kimchi for yogurt starters. LWT - Food Sci. Tech. 58: 130-134.

Li, M., Yang, D., Mei, L., Yuan, L., Xie, A., and Yuan, J. 2014. Screening and characterization of purine nucleoside degrading lactic acid bacteria isolated from Chinese sauerkraut and evaluation of the serum uric acid lowering effect in hyperuricemic rats. Plos one. 9: 1-12.

Lilly, D. M., and Stillwell, R. H. 1965. Probiotics: Growth-promoting Factors Produced by Microorganisms. Science. 147: 747-748.

Nahaisi, M. H., Ravisankar, S., and Noratto, G. D. 2014. Probiotics as a strategy to improve overall human health in 
developing countries. J. Prob. Health. 2(1): 1-9.

Owusu-Kwarteng, J., Tano-Debrah, K., Akabanda, F., and Jespersen, L. 2015. Technological properties and probiotic potential of Lactobacillus fermentum strains isolated from West African fermented millet dough. BMC Microbiology. 15(261): 1-10.

Park, S. Y., and Lim, S. D. 2015. Probiotics characteristics of Lactobacillus plantarum $\mathrm{FH} 185$ isolated from human feces. Korean J. Food Sci. An. 35(5): 615-621.

Radulovic, Z., Petrovic, T., Nedovic, V., Dimitrijevic, S., Mirkovic, N., Petrusic, M., and Paunovic, D. 2010. Characterization of autochthonous Lactobacillus paracasei strains on potential probiotic ability. Mljekarstvo. 60(2): 86-93.

Rawat, K., Kumari, A., Kumar, S., Kumar, R., and Gehlot, R. 2018. Traditional Fermented Products of India. Int. J. Curr. Microbiol. App. Sci. 7(4): 18731883.

Rubio, R., Jofre, A., Martin, B., Aymerich, T., and Garriga, M. 2014. Characterization of lactic acid bacteria isolated from infant faeces as potential probiotic starter cultures for fermented sausages. Food Microbiology. 38: 303-311.

Sayes, C., Leyton, Y., and Riquelme, C. 2018. Probiotic Bacteria as an Healthy Alternative for Fish Aquaculture. In:
Antibiotic use in animals (Eds.) $\mathrm{S}$. Savic. IntechOpen, London, Pp. 115132

Shehata, M. G., El-Sohaimy, S. A., El-Sahn, M. A., and Youssef, M. M. 2016. Screening of isolated potential probiotic lactic acid bacteria for cholesterol lowering property and bile salt hydrolase activity. Anals of Agricultural Science. 61(1): 65-75

Tallapragada, P., Rayavarapu, B., Rao, P. P., Ranganath, N. N., and Veerabhadrappa, P. P. 2018. Screening of potential probiotic lactic acid bacteria and production of amylase and its partial purification. Journal of Genetic Engineering and Biotechnolgy. 16: 357 362.

Yadav, R., and Shukla, P. 2015. An overview of advanced technologies for selection of probiotics and their expendiency: a review. Crit. Rev. Food Sci. Nutr.

Yadav, R., Puniya, A. K., and Shukla, P. 2016. Probiotic properties of Lactobacillis plantarum RYPR1 from an Indegenous fermented beverage raabadi. Frontiers in Microbiology. 7: 1-9.

Zielinska, D., Rzepkowska, A., Radawska, A., and Zielinski, K. 2015. In vitro screening of selected probiotic properties of Lactobacillus stains isolated from traditional fermented cabbage and cucumber. Curr. Microbiol. 70: 183-194.

\section{How to cite this article:}

Neha Khagwal, D.C. Sharma and Sharma, P.K. 2019. Isolation and Characterization of Potential Probiotic Strains Isolated from Traditional Indian Fermented Foods. Int.J.Curr.Microbiol.App.Sci. 8(03): 680-689. doi: https://doi.org/10.20546/ijcmas.2019.803.084 